Article

\title{
Post-COVID 19 Tourism: Will Digital Tourism Replace Mass Tourism?
}

\author{
Nadeem Akhtar 1(D), Nohman Khan 2,*(D), Muhammad Mahroof Khan ${ }^{3}$, Shagufta Ashraf ${ }^{4}$, \\ Muhammad Saim Hashmi ${ }^{5}$, Muhammad Muddassar Khan ${ }^{6}$ and Sanil S. Hishan ${ }^{7}$
}

check for updates

Citation: Akhtar, N.; Khan, N.; Mahroof Khan, M.; Ashraf, S.; Hashmi, M.S.; Khan, M.M.; Hishan, S.S. Post-COVID 19 Tourism: Will Digital Tourism Replace Mass Tourism? Sustainability 2021, 13, 5352. https://doi.org/10.3390/su13105352

Academic Editor: Gema Cárdenas

Received: 17 March 2021

Accepted: 27 April 2021

Published: 11 May 2021

Publisher's Note: MDPI stays neutral with regard to jurisdictional claims in published maps and institutional affiliations.

Copyright: (c) 2021 by the authors. Licensee MDPI, Basel, Switzerland. This article is an open access article distributed under the terms and conditions of the Creative Commons Attribution (CC BY) license (https:/ / creativecommons.org/licenses/by/ $4.0 /)$.
1 School of Urban Culture, Nanhai Campus, South China Normal University, Foshan 528225, China; nadeem@scnu.edu.cn

2 UniKL Business School, Universiti Kuala Lumpur, Kuala Lumpur 50300, Malaysia

3 Faculty of Social Sciences and Humanities, University of Kotli Azad Jammu and Kashmir, Kotli 11100, Pakistan; Khanhust@yahoo.com

4 Banking and Finance, University of Kotli Azad Jammu and Kashmir, Pakistan, Kotli, Azad Jammu and Kashmir 11100, Pakistan; xhagufta@yahoo.com

5 Department of Economics, Mirpur University of Sciences \& Technology, Mirpur Azad Kashmir 10250, Pakistan; saim.eco@must.edu.pk

6 Management Sciences, Abbottabad University of Science and Technology, Havelian 22000, Pakistan; drmudassarkhan@aust.edu.pk

7 Azman Hashim International Business School, Universiti Teknologi Malaysia (UTM), Skudai 81300, Malaysia; sshishan2@live.utm.my

* Correspondence: nohman.khan@s.unikl.edu.my

\begin{abstract}
Recently, nations are struggling to mitigate the impact of the unprecedented COVID-19 outbreak on their economy. Many countries have imposed traveling restrictions to reduce people's movement in order to avoid infection transmission. Traveling restrictions have jeopardized the tourism industry around the globe. If the situation persists, it will become challenging for the nations to open tourism. For this reason, the digitalization of tourism is a viable solution for this situation. However, it is essential to map whether digital technologies can provide alternative solutions to the situation and whether digital tourism can replace conventional tourism? With that backdrop, this study has two objectives: (a) to find the future of digital tourism development beyond the COVID-19 pandemic situation, and (b) to find collaborative research work among nations to develop digital tourism after the current pandemic crisis. To achieve these objectives, we conducted a systematic literature review of past research on the development of digital tourism from 2016-2020. The study applies the PRISMA-2015 statement to select and synthesize 60 articles from Scopus and 'Web of Science' databases. Content analysis was performed to analyze the underlying clusters of research on digital tourism and, later, bibliometric analysis was conducted to examine collaborative research between different countries. The findings highlighted three major research clusters namely; virtual reality tourism, virtual tourism, and augmented reality. In addition, the research finding shows that virtual tourism is a practical and valuable option for mass tourism during the COVID-19 outbreak and can replace mass tourism after the pandemic. Although virtual tourism does not feel like a visit to a natural destination, it is still getting attention from tourists. Virtual spaces must develop more features and value additions to achieve tourist satisfaction in the future.
\end{abstract}

Keywords: augmented reality; COVID-19; digital tourism; tourism; virtual reality

\section{Introduction}

The recent outbreak of COVID-19 is a real-time challenge that is affecting every part of the world. Directly from the health sector to other vital segments like economies, societies, and political difficulties, the pandemic reshapes the communities' social behaviors worldwide [1]. However, the major challenge is the travel and tourism industry in the postCOVID-19 world. The tourism industry is one of the significant contributors to the GDP of 
many tourist destinations globally. The tourism industry in the 21st century is anticipated to be a radical development of information and interaction tools. One such dramatic expression in establishing a tourist product is service in the hospitality industry, which is the beginning of an entirely innovative digital tourism path [2]. Digital technologies are a vital and integral part of many businesses in the world. Major economic segments are availing the digital technologies to enhance their capabilities [3]. Due to the substantial dependencies of economies on the tourism and hospitality industry, it is challenging for countries to avoid the importance of tourism revenues.

However, at the same time, the more significant challenge of social distancing and pandemic infection made it difficult for nations to avoid the situation. Some international tourist destinations and tourism activities are opening with the new normal in the current time. However, the condition is still critical in many parts of the world. Europe is paving the tourism destinations with the new standard SOPs; the other parts of the world are still struggling to prevent the COVID-19 outbreak [4]. The current situation is not favorable for the stellar opening of tourism destinations. Travel and tourism losses are limited to the few people and tourists to the local community; many dependents affect the current crises. That will lead many parts of the world to find alternative options for the tourism industry's survival [5]. Previously published studies on the outbreak's effect are not consistent about the future of tourism and uncertain situations related to the pandemic [6]. Sarkar et al. [7] argued that the current pandemic outbreak would shape individuals' and societies' behavior towards travel and tourism in other parts of the world. It will be very challenging for the governments to allow visitors in their countries due to a pandemic outbreak's threats.

The tourism industry needed a significant change to build a more substantial impact on potential tourists, and technological advancement is the tourism industry's premium future. Technological development is significantly inspiring many fields and commercial sectors within the COVID-19 outbreak. Supply chain processes are restructuring, while medical and manufacturing sectors also handle the situation with advancement in the procedures which use the technology [7]. The tourism industry can also be finding a better solution using the technology and Information Technology (I.T.) modern development for the survival of the industry. Virtual reality is one of many very modern and advanced progressions in the industrial revolution (IR4.0). Virtual tourism is a better and safer option for the tourism industry. Virtual travel is advancing with virtual reality and augmented reality to allow travelers to enjoy new places and destinations without leaving their homes [8]. The advanced technologies of virtual reality use the 360-degree visibility of the tourist's destinations that stimulate the urge to travel and entertain the unique experience $[9,10]$. Previous researchers contributed to the development of sustainable tourism using virtual reality and augmented reality in environmental sustainability. The current outbreak changes the situation where suddenly, due to lockdowns and movement control orders issued domestically, international suspensions of travel make this an alternative option for mass tourism [10]. The present study will appraise the overall progress and research related to the future of tourism after the COVID-19 outbreak.

Recent developments of technology advancement make it easier and more reliable for users to enhance their ability to explore the destinations. Researchers seek to develop a better tourism and traveling model to maintain a sustainable tourism mechanism [11]. This review aims to find the digital future of tourism development after the COVID-19 pandemic situation. This study's second objective is to find collaborative research work among the nations to develop the tourism industry after the current pandemic crisis. The current study is evaluating the past published research in the systematic literature review (SLR). The present study is drawing to assess the literature's progress published from 2016 to 2020 in the two reputed databases, Scopus and 'Web of Science'. The research question postulates that tourism's future is related to virtual reality and augmented reality after most countries' current movement control situation. For that purpose, we will look in detail in the literature to find the contribution related to the future of tourism and technology adoption to fulfill conventional tourism requirements. This study will also evaluate the 
reputed conclusion and findings of the past published literature on the future of tourism and virtual reality. The current study will do a comprehensive review using the data downloaded from Scopus and 'Web of Science'. For that purpose, PRISMA (2009) is used to screen the literature, and PRISMA is an excellent tool for using systematic reporting reviews. The use of PRISMA is constructive in the critical appraisal of previously published research [12]. That will fill the gap for the future researcher's direction and contribution to developing a conceptual model of tourism in the post-corona world. A robust and quality screening process is adopted to find better results from the literature.

\section{Materials and Methods}

In reporting the results and developing the research framework, authors worldwide are using the PRISMA statement 2015. The SLR is a guide to enhance the reviews and meta-analysis [13]. The PRISMA statement template explains the overall research process to select and reject articles in this SLR. This SLR base study is limited to published literature on the topic of digital technologies and tourism. The two actual databases, Scopus and 'Web of Science', are used for the literature extraction. The study also included recent reports and editorials on the tourism-related topic. The keywords are "digital tourism", "digital technologies", "virtual travel", "virtual reality and tourism", and "augmented reality and tourism" in the search bar. The database's total results showed 1286; for more clarity of the effects, the internal search option uses the inner search; the keyword future is used. The database showed 460 results. For the other process, subjects selected for the current study were social science, business, management and accounting, environmental science, and psychology topics selected, results were narrowed down to 209. The final published articles selected in the press and other materials do not consist of the review. Figure 1 is showing the details of PRISMA statement 2015 selection and rejection process.

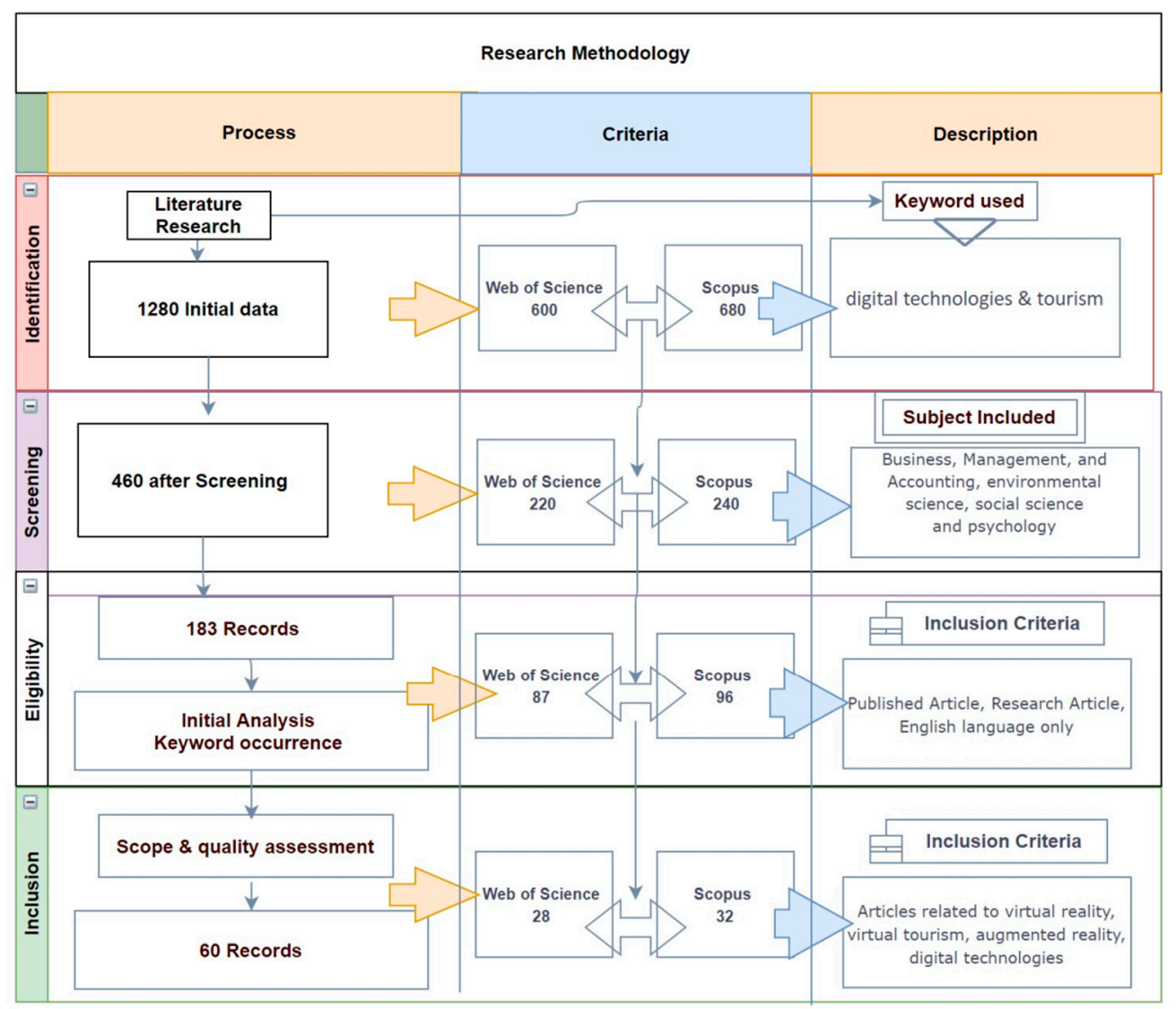

Figure 1. PRISMA 2015 selected and rejected criteria. 


\section{Results}

\subsection{Descriptive Analysis}

The final 60 studies further divide the subject base. The studies' allocation based on subject categories indicated that the business, management, and accounting subjects contributed to the highest number, with 22 articles in the current study for review. The second-largest papers are selected from the topic of environmental science with 17 . The third-highest numbers of research papers were chosen from social science, which is 15 , and six studies were also picked from the psychology discipline. Figure 2 is showing the results of the subject-wise selection of the articles for the current research.

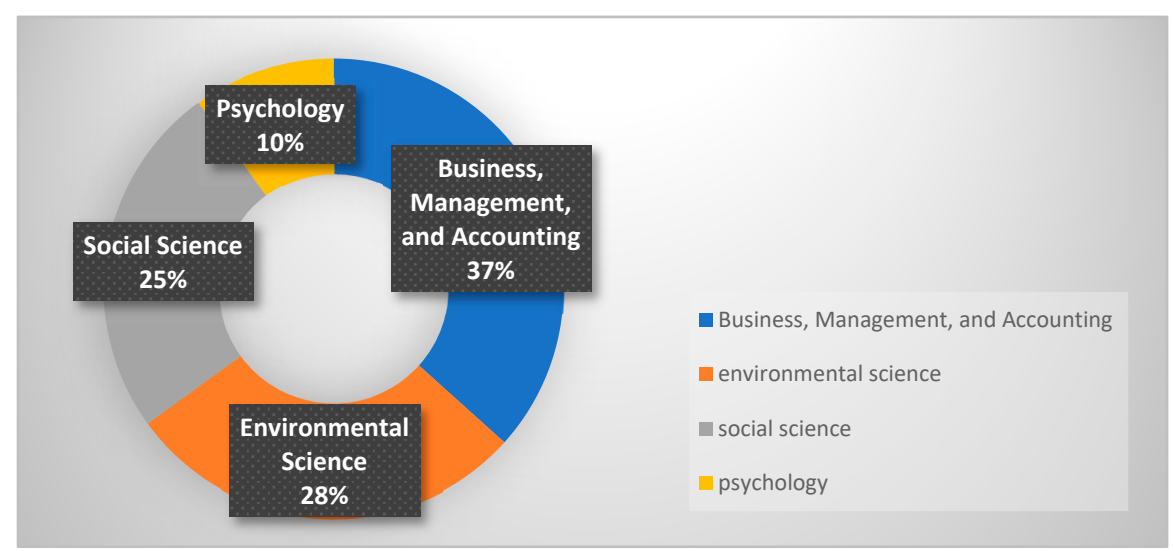

Figure 2. The distribution of research on the subject base.

The study is not focusing on the specific time frame of the articles in whichever year they were published. The year-wise distribution's primary purpose is to understand the number of publications in a year that selected and fulfilled the review's criteria. Figure 3 shows the year base graph of literature from 2016 to 2020. The year 2019 contributed the highest number with 21 articles. The year 2016 is second on the list with 16 research papers on tourism. The year 2017 added 13 studies. Figure 3 is showing the detailed information of articles selected from different years.

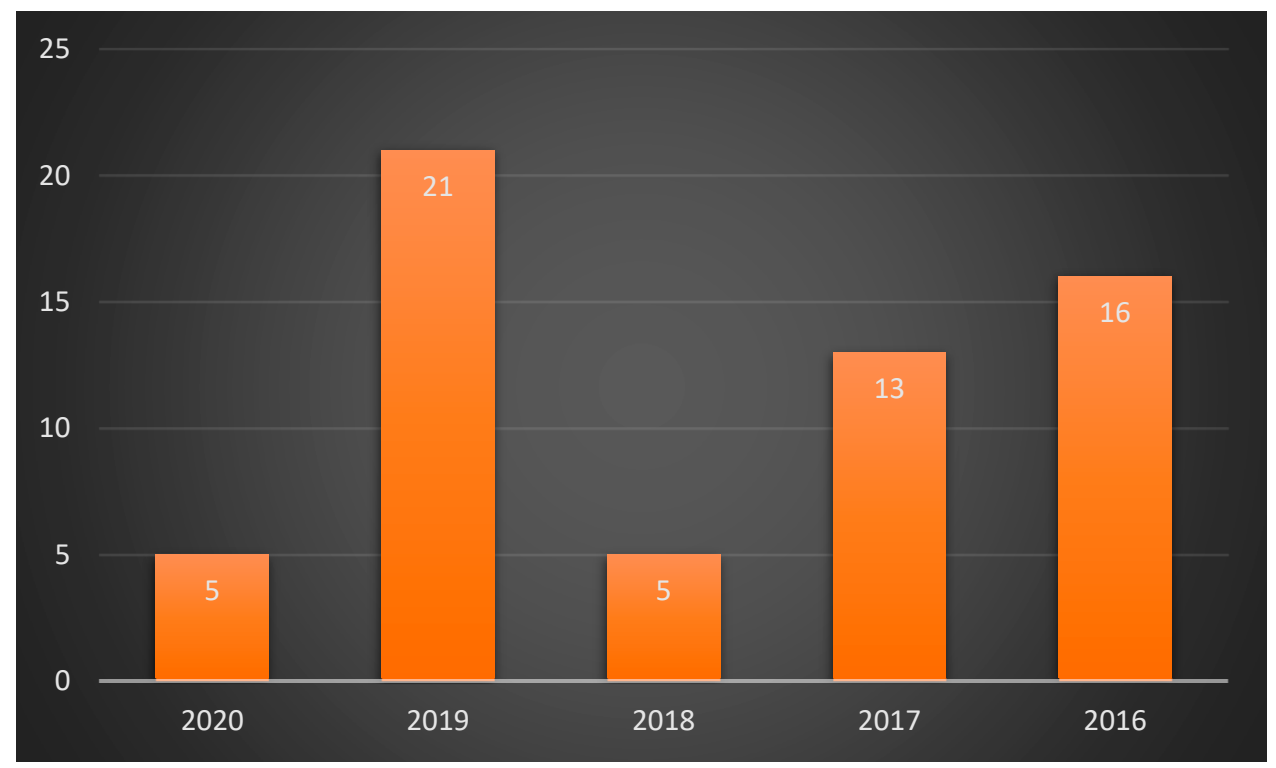

Figure 3. Distribution of the published literature.

Furthermore, the journal-based publication analysis is conducted for the current study and finds that the tourism management perspective journal contributes the highest 
articles. Second, most articles are selected from the International Journal of Tourism Research. Gradually, the name of the studies is going down for the current study. The International Journal of Tourism Research and Sustainability (Switzerland) has contributed articles from both journals. Figure 4 is showing the results of the research article selected from each journal.

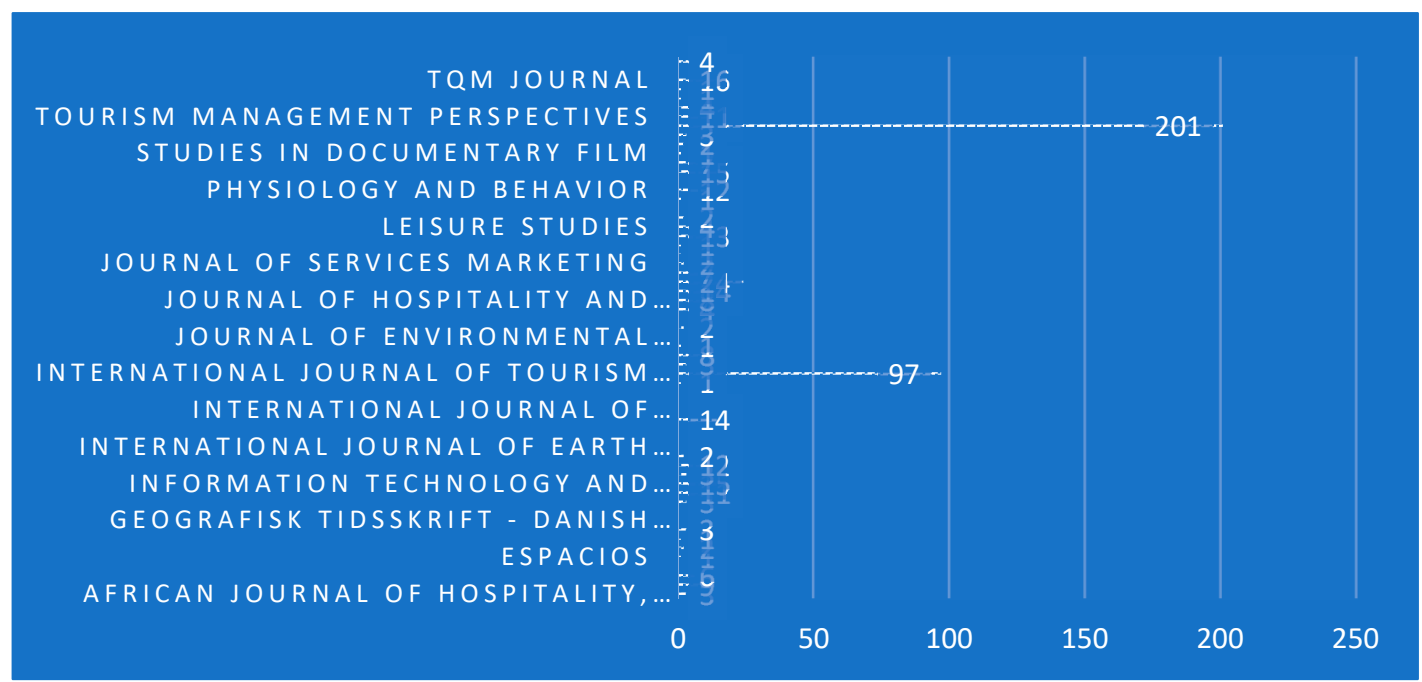

Figure 4. The distribution of research source title.

\subsection{Classifications of Literature}

Digital technologies are growing continuously, and researchers are looking deep into these technological changes step by step. Different technologies are used in digital tourism in the digital era- the current study evaluates the technology utilization for the tourism sector. Further classification of technologies drives the literature and researcher perspective toward technology adaptation in the tourism industry. The digital technologies literature is mostly discussing mostly researchers for the development of healthcare. The authors used the keyword clouding technique to identify the most frequent keywords used in the studies. As mentioned above, there were 183 studies included in the keyword clouding technique at literature review stage 1 ; further, these studies were used to identify the literature classifications from these keywords, as shown in Table 1.

Table 1. Keyword occurrences and relevance score.

\begin{tabular}{cccc}
\hline Term & Occurrences & Relevance Score & Cluster Affiliation \\
\hline Accessibility & 11 & 0.5601 & Digital tourism \\
\hline Adoption & 18 & 0.8411 & Digital technologies \\
\hline Architecture & 22 & 1.2726 & Digital tourism \\
\hline Attitude & 17 & 1.1721 & Digital tourism \\
\hline Augmented reality & 48 & 0.6103 & Augmented reality \\
\hline Augmented reality technology & 13 & 1.1876 & Augmented reality \\
\hline Behavior & 25 & 0.7555 & Digital tourism \\
\hline Combination & 13 & 0.8864 & Digital technologies \\
\hline Communication & 28 & 0.6362 & Digital technologies \\
\hline
\end{tabular}


Table 1. Cont.

\begin{tabular}{|c|c|c|c|}
\hline Term & Occurrences & Relevance Score & Cluster Affiliation \\
\hline Communication technology & 22 & 1.301 & Digital technologies \\
\hline Community & 37 & 1.7189 & Digital tourism \\
\hline Company & 20 & 1.088 & Digital technologies \\
\hline Computer & 14 & 1.5764 & Digital technologies \\
\hline Consumer & 29 & 0.9394 & Digital tourism \\
\hline Content & 35 & 0.5187 & Digital technologies \\
\hline Creation & 33 & 0.7548 & Digital technologies \\
\hline Cultural heritage & 25 & 2.0259 & Virtual reality \\
\hline Cultural tourism & 14 & 0.9845 & Virtual reality \\
\hline Customer & 18 & 0.794 & Digital tourism \\
\hline Destination & 64 & 0.3845 & Virtual reality \\
\hline Education & 26 & 0.6654 & Virtual reality \\
\hline Effect & 41 & 0.4718 & Virtual reality \\
\hline Emergence & 12 & 0.7442 & Digital technologies \\
\hline Entertainment & 11 & 0.8032 & Virtual reality \\
\hline Evolution & 17 & 1.3053 & Social media \\
\hline Experiment & 22 & 0.9922 & Social media \\
\hline Future research & 15 & 0.2935 & Virtual reality \\
\hline Game & 17 & 0.9626 & Virtual reality \\
\hline Gap & 15 & 0.7606 & Virtual reality \\
\hline Goal & 21 & 0.8351 & Digital tourism \\
\hline Heritage & 25 & 1.6621 & Virtual reality \\
\hline History & 18 & 1.8859 & Digital tourism \\
\hline Ict & 14 & 1.0893 & Digital technologies \\
\hline Idea & 21 & 0.4854 & Social media \\
\hline Impact & 53 & 0.3791 & Social media \\
\hline Implication & 42 & 1.3608 & Digital technologies \\
\hline Influence & 21 & 1.1736 & Social media \\
\hline Information technology & 24 & 0.4153 & Virtual reality \\
\hline Innovation & 29 & 0.3825 & Virtual reality \\
\hline Internet & 35 & 0.7206 & Digital technologies \\
\hline Interview & 22 & 1.2014 & Digital technologies \\
\hline Landscape & 18 & 1.226 & Digital tourism \\
\hline Location & 29 & 1.1448 & Social media \\
\hline Marketing & 31 & 0.6573 & Social media \\
\hline Medium & 27 & 0.5263 & Social media \\
\hline Mobile device & 12 & 2.0977 & Digital technologies \\
\hline Museum & 21 & 1.0723 & Digital tourism \\
\hline New technology & 14 & 0.5103 & Virtual reality \\
\hline
\end{tabular}


Table 1. Cont.

\begin{tabular}{|c|c|c|c|}
\hline Term & Occurrences & Relevance Score & Cluster Affiliation \\
\hline Organization & 34 & 0.5591 & Digital tourism \\
\hline Overview & 15 & 1.8398 & Digital technologies \\
\hline Participant & 30 & 0.516 & Digital tourism \\
\hline Planning & 27 & 0.6501 & Digital technologies \\
\hline Project & 38 & 0.857 & Augmented reality \\
\hline Rapid development & 10 & 2.5559 & Digital technologies \\
\hline Relationship & 43 & 0.8375 & Augmented reality \\
\hline Researcher & 18 & 0.4483 & Digital technologies \\
\hline Social medium & 11 & 2.3991 & Augmented reality \\
\hline Space & 39 & 0.5775 & Augmented reality \\
\hline State & 29 & 1.0498 & Augmented reality \\
\hline Strategy & 35 & 0.5498 & Augmented reality \\
\hline Structure & 20 & 0.7301 & Augmented reality \\
\hline Tour & 32 & 0.8759 & Augmented reality \\
\hline Tourism destination & 26 & 0.5615 & Augmented reality \\
\hline Tourism experience & 19 & 0.5008 & Virtual reality \\
\hline Tourism marketing & 15 & 0.4398 & Social media \\
\hline Tourism product & 12 & 0.6677 & Virtual reality \\
\hline Tourism sector & 27 & 0.7302 & Virtual reality \\
\hline Tourist attraction & 14 & 1.9486 & Digital tourism \\
\hline Tourist destination & 17 & 1.2581 & Digital tourism \\
\hline Training & 17 & 0.7982 & Digital technologies \\
\hline Traveler & 14 & 0.4503 & Digital technologies \\
\hline User experience & 14 & 0.9117 & Virtual reality \\
\hline Video & 32 & 1.1073 & Virtual reality \\
\hline Virtual community & 30 & 2.4001 & Virtual reality \\
\hline Virtual experience & 15 & 0.7811 & Virtual reality \\
\hline Virtual reality technology & 36 & 0.9235 & Virtual reality \\
\hline Virtual tour & 31 & 0.7862 & Virtual reality \\
\hline Virtual world & 20 & 0.7232 & Virtual reality \\
\hline Visualization & 20 & 2.9095 & Augmented reality \\
\hline Vr technology & 30 & 0.5182 & Virtual reality \\
\hline Web & 20 & 0.6348 & Virtual reality \\
\hline Website & 15 & 1.0747 & Virtual reality \\
\hline
\end{tabular}

Literature was further analyzed for classification of research through the content analysis. Published articles are analyzed using the VOS Viewer software and exploring the content classification. The cluster-linked concepts are used to create data networks. Recent research verified that the author keywords included in the publications' indexation method in the databases are similarly helpful for bibliometric analysis designed to study the forms of research areas [14]. Hence, we used both types of keywords for the co-occurrence study within the research field related to virtual tourism. In total, 60 records were included in the research, and the data provided 2401 keywords. The first purple cluster indicates 
virtual tourism, 3D models, applications, and papers studied. The blue cluster indicates the clinical trials to find a suitable response to the pandemic outbreak, while the red cluster discusses the outbreak control and disaster management-related studies. The yellow clusters designate tourism, tourists, and tourism industry studies. The third cluster is indicating the development, article, and order studies co-occurrence. The last cluster is two frequencies of information, and the model is studied in the literature. Figure 5 indicates the text frequency co-occurrence.

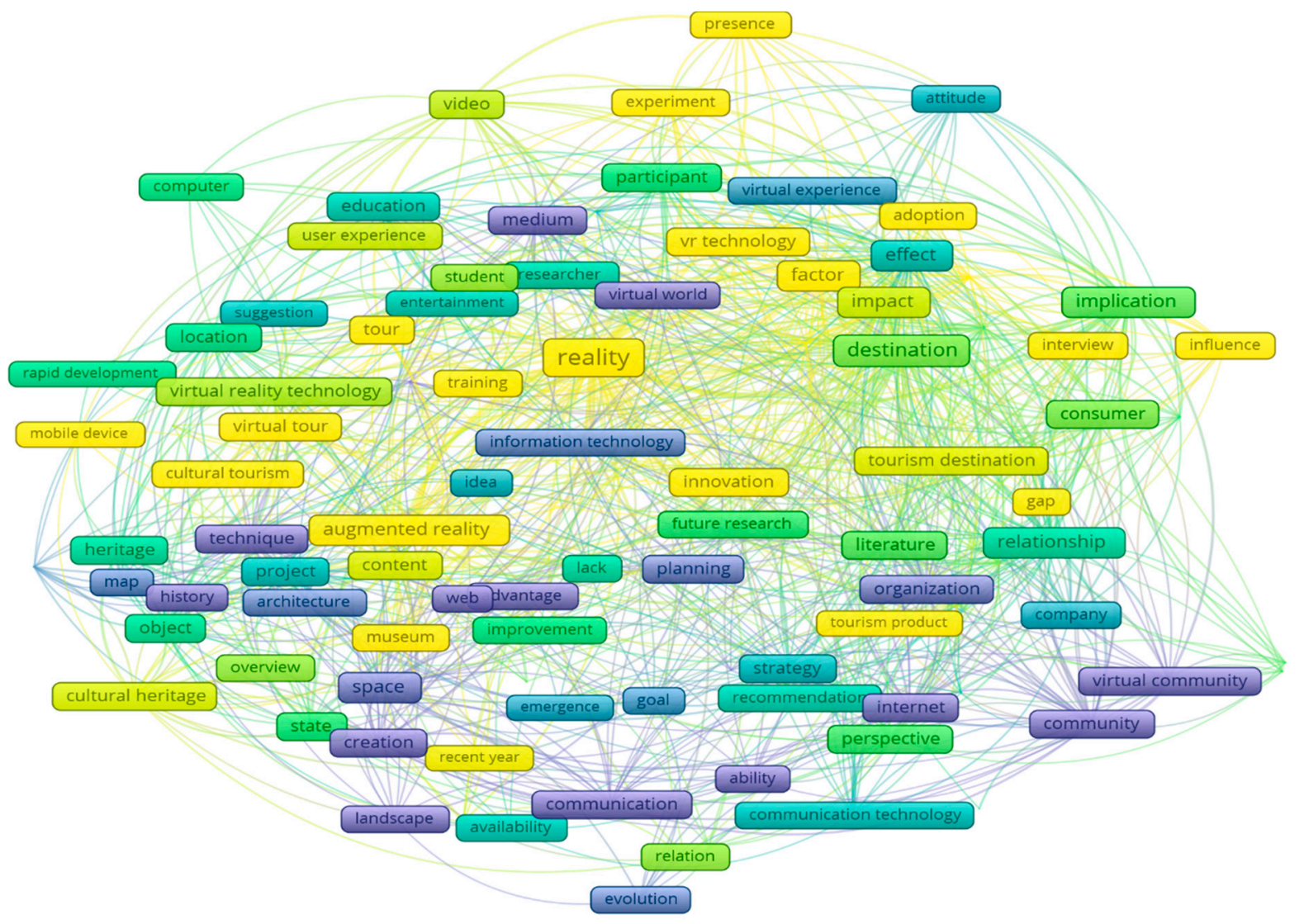

Figure 5. Research classifications using the text network technique.

\subsection{Digital Tourism}

Tourism research recently focuses on the newly developed application of high technology for marketing purposes such as mobile phones, mobile apps, and virtual reality. Among the many other applications, virtual reality is one of the most novel mediums [15]. As for the current study data classification, the highest number of studies are tourism and digitalization. The other reason is that the recent outbreak of COVID-19 allows researchers to look into the tourism industry's future development. Digitalization is changing the traditional way of tourism in recent times [16,17]. Bogicevic et al. [18] conducted an empirical study to find potential destination marketing through digital marketing technologies. The article's results and findings show that digital preview provokes elaboration towards the imagery and robust sense of presence. The research also suggests that VR is significant in triggering tourists to "daydream" about staying offers before experiencing them at the destination's premises. Tussyadiah et al. [19] argue that virtual reality in tourism offers more meaningful content for tourism. It is also opening new understandings and intentions for destination tourism. The study used 900 participants from Hong Kong and the U.K. study findings show that the virtual environment increases tourists' enjoyment through the VR experience. The study also concluded that positive attitude change leads to a higher level of visitation intention to a tourist destination. The research's empirical 
findings show that virtual reality shapes consumer attitudes and behavior towards virtual reality. Rejón-Guardia et al. [20] also organize the research to measure the factors that make visitors intend to visit virtual reality destinations. The author developed a theoretical framework including authentic experience, cognitive and affective responses, attachment, and visit intention with V.R. tourism using a stimulus-organism-response (SOR) theory. The findings of the study show that the plan to visit places significantly increases by virtual reality attachment. The authors also explain that the tourists visiting the destinations are more likely attached to virtual reality.

However, cultural tourism is also very much beneficial through virtual reality applications. The visitors are visiting the museum, and feelings with perceptions are generated through virtual reality. The cultural tourism-related research findings show that virtual reality is mediating the relationship between experience and emotional feelings [21].

Virtual reality perceptions and attitudes also largely depend on the underdeveloped and developed nations' education toward tourism and technology. Qureshi et al. [15] showed the concerns about Nigeria's virtual reality as a developing nation. The study provides a tip to policymakers and academia of the ups and downs of VR application in developing nations. Due to VR's volatile future, attraction to adjacent countries and nations with interest in tourism keeps growing daily. The low GDP and economically positioned nations lack the infrastructure to support the virtual reality tour and cannot promote the matter. Virtual reality is an emerging tool in the experience and design enhancement to develop the tourism and hospitality industry. Kim \& Hall [22] used the hedonic motivation system adoption model (HMSAM) for virtual reality in the visitation and engagement of travel activities and behaviors. The study importantly investigated that for destination association between usefulness and flow state, it had a significant moderating effect on whether someone was a visitor or non-visitor. The finding of the study shows that virtual tourism is suitable for future visitors. However, In his study, Han \& Dieck [23] suggested identifying the tourists' needs and demands about virtual reality. According to that design, the methodology focused on is the design process at the first step. Table 2 shows the overall classification, qualitative, quantitative, settings, and segmentation of the literature. The table also explains the findings of past research.

Table 2. Digital tourism.

\begin{tabular}{|c|c|c|c|c|}
\hline Authors & Methodology & Procedures & Settings & Findings \\
\hline $\begin{array}{l}\text { Qureshi et al. (2020) } \\
\text { [15] }\end{array}$ & Quantitative & marketing practices & tourists' destinations & $\begin{array}{l}\text { This research provides valuable insights } \\
\text { into how this new technology might } \\
\text { function as a tool for marketing Jinan, a } \\
\text { tier-two but historically significant } \\
\text { destination in China. }\end{array}$ \\
\hline $\begin{array}{c}\text { Bogicevic et al. (2019) } \\
\text { [18] }\end{array}$ & Quantitative & destination marketing & $\begin{array}{l}\text { lab-coordinated } \\
\text { experiment }\end{array}$ & $\begin{array}{l}\text { Findings suggest that VR is substantial in } \\
\text { prompting tourists to "daydream" about } \\
\text { lodging offers before experiencing them at } \\
\text { the destination's premises. }\end{array}$ \\
\hline $\begin{array}{l}\text { Tussyadiah et al. } \\
\text { (2018) [19] }\end{array}$ & quantitative & visitation intention & empirical & $\begin{array}{l}\text { Therefore, this study provides empirical } \\
\text { evidence to confirm VR's effectiveness in } \\
\text { shaping consumers' attitudes and behavior. }\end{array}$ \\
\hline $\begin{array}{l}\text { Rejón-Guardia et al. } \\
\qquad(2020) \\
{[20]}\end{array}$ & $\begin{array}{l}\text { theoretical } \\
\text { framework }\end{array}$ & visit intention. & tourists' destinations & $\begin{array}{l}\text { The results demonstrated that the intention } \\
\text { to visit places shown in VR tourism was } \\
\text { influenced by attachment to VR. Cognitive } \\
\text { response had a more substantial influence } \\
\text { than the affective response to visiting a VR. } \\
\text { This study sheds light on why potential } \\
\text { tourists visit destinations shown in VR. }\end{array}$ \\
\hline
\end{tabular}


Table 2. Cont

\begin{tabular}{|c|c|c|c|c|}
\hline Authors & Methodology & Procedures & Settings & Findings \\
\hline $\begin{array}{l}\text { Errichiello et al. (2019) } \\
\text { [20] }\end{array}$ & Quantitative & cultural tourism & museum visitors & \\
\hline $\begin{array}{l}\text { Kim \& Hall, (2019) } \\
\text { [21] }\end{array}$ & Quantitative & consumers & $\begin{array}{c}\text { travel activities and } \\
\text { behaviors }\end{array}$ & $\begin{array}{l}\text { The findings offer new knowledge to } \\
\text { researchers and industry in the VR } \\
\text { tourism fields. }\end{array}$ \\
\hline $\begin{array}{l}\text { Han \& Dieck, (2019) } \\
\text { [23] }\end{array}$ & Quantitative & consumers & $\begin{array}{l}\text { hospitality and tourism } \\
\text { industry }\end{array}$ & $\begin{array}{l}\text { To achieve this, the authors recommend } \\
\text { using design methodology to focus on the } \\
\text { first steps in the design process to identify } \\
\text { and understand customers' needs and } \\
\text { desires independent of VR technology. }\end{array}$ \\
\hline $\begin{array}{c}\text { Jude Chigozie, (2020) } \\
{[24]}\end{array}$ & secondary data & consumers & $\begin{array}{l}\text { tourism planning and } \\
\text { promotion }\end{array}$ & $\begin{array}{l}\text { the study serves as a pointer to } \\
\text { policymakers and academia of the } \\
\text { vicissitudes of VR application in } \\
\text { developing nations, with attendant value } \\
\text { to neighboring countries and nations with } \\
\text { interest in tourism due to the unpredictable } \\
\text { future of VR, which keeps evolving daily }\end{array}$ \\
\hline
\end{tabular}

The future related to virtual reality and tourism is very much consistent with virtual reality devices. Flavián et al. [25] organized a lab experiment on the device's base experience; lab experiment shows linking to desktop, PC and mobile phones, VR's headmounted displays generate more immersive experiences, higher sensory encouragement, more engagement, and higher social intentions toward the destination. Virtual reality studies are generally concerned with user-centric models and are based on their experience. The researchers are more focused on developing virtual reality devices that intend to visit tourists' destinations. The literature is not enough evidence to replace traditional tourism.

\subsection{Virtual Reality}

The classification of the current study's literature, the second most published articles on the virtual reality area, is included. The virtual reality-related studies are the qualitative methodology used by the authors. Virtual reality is a demonstration tool for destination marketing and valuable for tourism marketing. Moorhouse, [26] argues that a minimal number of exploratory studies provide the empirical perspective of tourism marketing. The author's findings are related to the environmental factors associated positively with the tourism markets and adaptation of virtual reality. The adaptation of virtual reality is significantly improving destination tourism. The tourism industry is working on adapting technological development and transformational technology to the event industry's vital users. That is an alternative technique to provide an entertaining experience to the visitors [27]. The study findings suggest that virtual reality events are innovative and an extension of the entertainment industry, but the replacement of live events and tours is not yet here. What remains evident is that the current form of virtual reality does not provide the social and sensory gratifications of live events. However, virtual reality is a vital key component in the situated experiential education environment and influences the users to participate in the virtual spaces. Real-world experiences are a costly and time-consuming process. For that need, very long visa processing and permissions for the countries' tourism destinations and sometimes people are refused entry in the host country. Louw \& Louw [28] found that virtual reality can provide the visitors' entire experience, and researchers need to identify the virtual reality spaces for the industry to alternate the real-time tourism experience. The study's findings suggest that a situated experiential education environment is a unique challenge for the researchers.

The recent decade is highly innovative and technology-oriented from the social development of the entertainment and tour industry. Virtual spaces enhance the meaning of the users' experience, from the home to the market [29]. The researchers need to work on the individual motivational factors for virtual nature tours. Marasco \& Balbi [30] show 
the result of the study related to virtual tourism. The 299 tourists who were asked the questions suggested that the study's findings are better received among women, lower educated people, and 50-70-year-olds; these may be ideal target groups for promoting virtual nature experiences. The higher the age, people perceive more intention towards virtual tourism. That is also leading to the cultural and heritage virtual tours from the customers' centric perspective. Cultural and heritage tourism experiences can be created using virtual reality needs. The study uses multi-method explorative research, personas and scenarios are developed to inform the subsequent co-design of virtual reality solutions along the visitors' journey [31]. However, virtual reality is based on the visitor intentions they perceive from the different social networking sites. Schott \& Marshall [32] use the stimulus-organism-response (S-O-R) framework for the impact of social networking sites on the virtual tour in the Jordan tourism perspective. The study's findings show that affective and cognitive states were impacted by atmospherics more than online flow; however, affecting states tend to describe more alterations in visiting intentions vis-à-vis virtual clusters. Effects and suggestions are involved in developing robust tourist centers efficient in inviting tourists' visiting plans.

Table 3 is showing the overall setting, procedures, and classification of the literature from past research. In their study, suggested using the Technology Acceptance Model (TAM) for the tour-guiding platform. The study's findings show that the education of the tourist's guide indicates their learning effectiveness and technology use. That affects the overall tour of the visitors during the destinations traveling. Although virtual reality is an essential element in tourism development, technological disruptions are fundamental to virtual reality. Buhalis et al. [33] and Han et al. [34] conducted a study to find technological disruption. Findings emphasize the necessity for research into provision innovations in the tourism and hospitality sectors at both macro-market and micro-firm levels, originating from rapid and extreme technological advancements. Specifically, the paper identifies three sections of expected future disruption in-service events that may benefit from instant attention: extra-physical skills, hyper-customized capabilities, and beyond-computerization experiences.

Table 3. Virtual reality.

\begin{tabular}{|c|c|c|c|c|}
\hline Authors & Methodology & Procedures & Settings & Findings \\
\hline $\begin{array}{l}\text { Orru et al. (2019) } \\
\text { [29] }\end{array}$ & qualitative & responsible tourism & tourist destinations & $\begin{array}{l}\text { Other stakeholders could use new } \\
\text { emerging technologies, such as virtual } \\
\text { reality, to offer tourists the } \\
\text { opportunity to experience tourism } \\
\text { products and places before traveling. }\end{array}$ \\
\hline $\begin{array}{l}\text { Schott \& Marshall, } \\
\text { (2018) [32] }\end{array}$ & qualitative & virtual environment & experiential education & $\begin{array}{l}\text { The results demonstrate that complex } \\
\text { immersive learning environments are } \\
\text { readily achievable but that high levels } \\
\text { of interactivity remain a challenge }\end{array}$ \\
\hline $\begin{array}{c}\text { Moorhouse, (2019) } \\
\text { [26] }\end{array}$ & qualitative & $\begin{array}{l}\text { destination } \\
\text { marketing }\end{array}$ & explanatory & $\begin{array}{l}\text { Finally, theoretical contributions, } \\
\text { practical implications, and avenues for } \\
\text { further research are provided. }\end{array}$ \\
\hline $\begin{array}{l}\text { Buhalis et al. (2019) } \\
\text { [33] }\end{array}$ & qualitative & consumers & events & Uses and Gratifications (UG) Theory \\
\hline
\end{tabular}


Table 3. Cont

\begin{tabular}{|c|c|c|c|c|}
\hline Authors & Methodology & Procedures & Settings & Findings \\
\hline $\begin{array}{l}\text { (Marasco \& Balbi, } \\
\text { (2019) [30] }\end{array}$ & qualitative & visitors' perspective & heritage destinations & $\begin{array}{l}\text { Through multimethod explorative } \\
\text { research, personas and scenarios are } \\
\text { developed to inform the subsequent } \\
\text { co-design of virtual reality solutions } \\
\text { along the visitors' journey }\end{array}$ \\
\hline $\begin{array}{l}\text { Louw \& Louw, } \\
\text { (2018) [28] }\end{array}$ & Quantitative & $\begin{array}{l}\text { Pro-ecological } \\
\text { beliefs }\end{array}$ & tourism research & $\begin{array}{l}\text { As VT is better received among } \\
\text { women, lower educated people, and } \\
50-70 \text {-year-olds, these may be ideal } \\
\text { target groups for the promotion of } \\
\text { mediated nature experiences }\end{array}$ \\
\hline
\end{tabular}

\subsection{Augmented Reality and Social Media Tourism}

Technology innovation is principally vital for those who are involved in travel and tourism-related businesses. Augmented reality is a significant selling experience, and environments related to augmented reality can influence tourism's diverse manners [35]. In the current review, a study contributes to the adaptation problems related to augmented reality in urban tourism environments that help in sustainable social tensions, social rehabilitation, and participating in the tourist's services. The study concluded that digital mediums and social media platforms' development are crucial for tourism services and social sustainability. However, Barrado-Timón \& Hidalgo-Giralt [36] conducted a study to investigate the impact of augmented reality and virtual reality on the theory, comprehension, and use of urban heritage spaces. The conclusions and assumptions of the study show that those concerns around the dangerous features are minimal. Through observation, the possible risks found were that of trivialization of heritage, the construction of virtual tourist worlds distinct from the physical galaxy of socio-economic relatives.

Additionally, the undesirable properties on how information is built or the problems for some user groups in retrieving these technologies were found. Augmented reality and virtual reality form new travel and tourism environments in recent times, which are also adopted by many industries as a marketing tool [37]. The tourism industry practitioners recognize the augmented reality as a very promising experimenting potential. A study contributes to the museum experience and users' purchase intention through augmented reality in the recent review. Using an experimental approach for research and results, the study concluded that augmented reality significantly influences the purchase decision in museum-related products [38]. Although the travel and tourism industry have a significant dependency on virtual reality and augmented reality, social media platforms are crucial for marketing. Destination marketing using the augmented reality and virtual reality experience needs social media marketing to engage the users with these technologies. For example, users may argue their mobile at a restaurant, instantly provide reviews or menus, or aim their tablet at a historic landmark and be presented with information about its history [31]. Coghlan \& Carter (2020) [39] conducted the study using the Design-PlayExperience Model's gaming conceptual framework and to find the interactions with the game. The conclusions demonstrate how games can be created to symbolize a complicated and endangered ecosystem and provoke positive feelings between tourists, exceptionally novelty, and pleasure. The development of virtual reality devices is more frequently penetrating the tourism industry, and users are looking for better services to experience.

Social media-related studies selected in recent research related to the future of tourism marketing and virtual reality perspective. Muñoz-Leiva et al. (2019) [40] conducted a study analyzing social media's advertising effectiveness regarding users' and customers' visual attention and recalling the memory. The quantitative study findings explain better advertising efficiency in the hotel social network's travel case, and visible attention measures established on eye-tracking data differed from self-reported recall measures. The social media mediums help develop the local and domestic tourists' destinations to the 
international forum through the broader community reach. Cross-cultural communication is the primary source of a direct connection between the representatives of different nations and cultures. In the age of internet communication and virtual reality, the mediums are changing into digital communication sources. According to AZAROVA et al. [41] study results findings, new scientific discussion of cross-cultural communication in international tourism contains a wide range of beliefs in various social aspects, such as globalization, freedom of movement, bulk movement people, and establishment of new cultural communities. With social media platforms and communications, the innovation of high-resolution games and features is also beneficial in destination tourism marketing. Much augmented reality and virtual reality video game developers use cultural and heritage destinations to promote tourism. Table 4 is showing the details of the author's findings.

Table 4. Augmented reality and social media.

\begin{tabular}{|c|c|c|c|c|}
\hline Authors & Methodology & Procedures & Settings & Findings \\
\hline $\begin{array}{c}\text { Keckes \& Tomicic, } \\
\text { (2017) } \\
{[35]}\end{array}$ & qualitative & cultural tourism & visitor adoption & $\begin{array}{c}\text { Findings inform an ARSG adoption } \\
\text { framework that integrates societal impact, } \\
\text { perceived benefits, perceived attributes of } \\
\text { innovation, and visitor resistance as the } \\
\text { main themes of ARSG adoption in } \\
\text { cultural tourism }\end{array}$ \\
\hline $\begin{array}{c}\text { Barrado-Timón \& } \\
\text { Hidalgo-Giralt, (2019) } \\
\text { [36] }\end{array}$ & Reality & $\begin{array}{l}\text { the urban } \\
\text { environment in } \\
\text { tourism }\end{array}$ & digital development & $\begin{array}{l}\text { New perspective directions are proposed to } \\
\text { improve the institutional environment and } \\
\text { sustainable positive dynamics of social } \\
\text { rehabilitation, reduce social tensions, and } \\
\text { fill free time for recipients of tourist } \\
\text { services. The vectors of territories' digital } \\
\text { development are determined. }\end{array}$ \\
\hline $\begin{array}{l}\text { He et al. } \\
\text { (2018) [37] }\end{array}$ & qualitative & museum tourism & experimental & $\begin{array}{l}\text { Using an experimental approach, the } \\
\text { results demonstrate that compared with } \\
\text { dynamic visual cues. Dynamic verbal cues } \\
\text { lead to visitors' higher levels of willingness } \\
\text { to pay more. Such an effect is more salient } \\
\text { when environmental augmentation } \\
\text { provides a high level of virtual presence. } \\
\text { The psychological mechanism of mental } \\
\text { imagery can explain such effects. }\end{array}$ \\
\hline $\begin{array}{c}\text { Gibson \& O'Rawe, } \\
\text { (2018) [38] }\end{array}$ & qualitative & urban heritage spaces & tourists & $\begin{array}{l}\text { Our main conclusion is that concerns } \\
\text { around the critical aspects are minimal, } \\
\text { with only a few perceiving the possible } \\
\text { dangers of trivialization of heritage, the } \\
\text { creation of virtual tourist worlds separate } \\
\text { from the material space of socio-economic } \\
\text { relations, adverse effects on how } \\
\text { knowledge is constructed, or the } \\
\text { difficulties for some user groups in } \\
\text { accessing these technologies. }\end{array}$ \\
\hline $\begin{array}{c}\text { Coghlan \& Carter } \\
\text { (2020) } \\
{[39]}\end{array}$ & Quantitative & $\begin{array}{l}\text { advertising } \\
\text { effectiveness }\end{array}$ & websites & $\begin{array}{l}\text { Visual attention to the ad banner was paid } \\
\text { at a low level of awareness, explaining why } \\
\text { the ad's associations did not activate its } \\
\text { subsequent recall. }\end{array}$ \\
\hline
\end{tabular}

\subsection{Collaborative Work on Digital Tourism}

Although the previous studies on virtual reality and tourism explain the relationship between virtual reality and tourism, the future of tourism is still not sure regarding conventional traveling after the recent COVID-19 pandemic. At the current time frame, mostly, researchers are looking for alternative options to continue the tourism and hospitality industry. To explore that, the authors conducted a detailed bibliometric analysis of past studies based on two fundamental parameters, a collaboration between the authors about virtual tours and the second parameter is terms used by the researchers. That gives us the idea to cluster the major collaboration areas of research. Figure 6 indicates the 
results of collaboration between the authors and co-authors in different countries. We used VOS viewer software for bibliometric analysis. The result indicated that there are three significant collaborations between China and the United States. China has the highest number of collaborations with other countries. The United States authors do the second most collaboration with the different country's researchers.

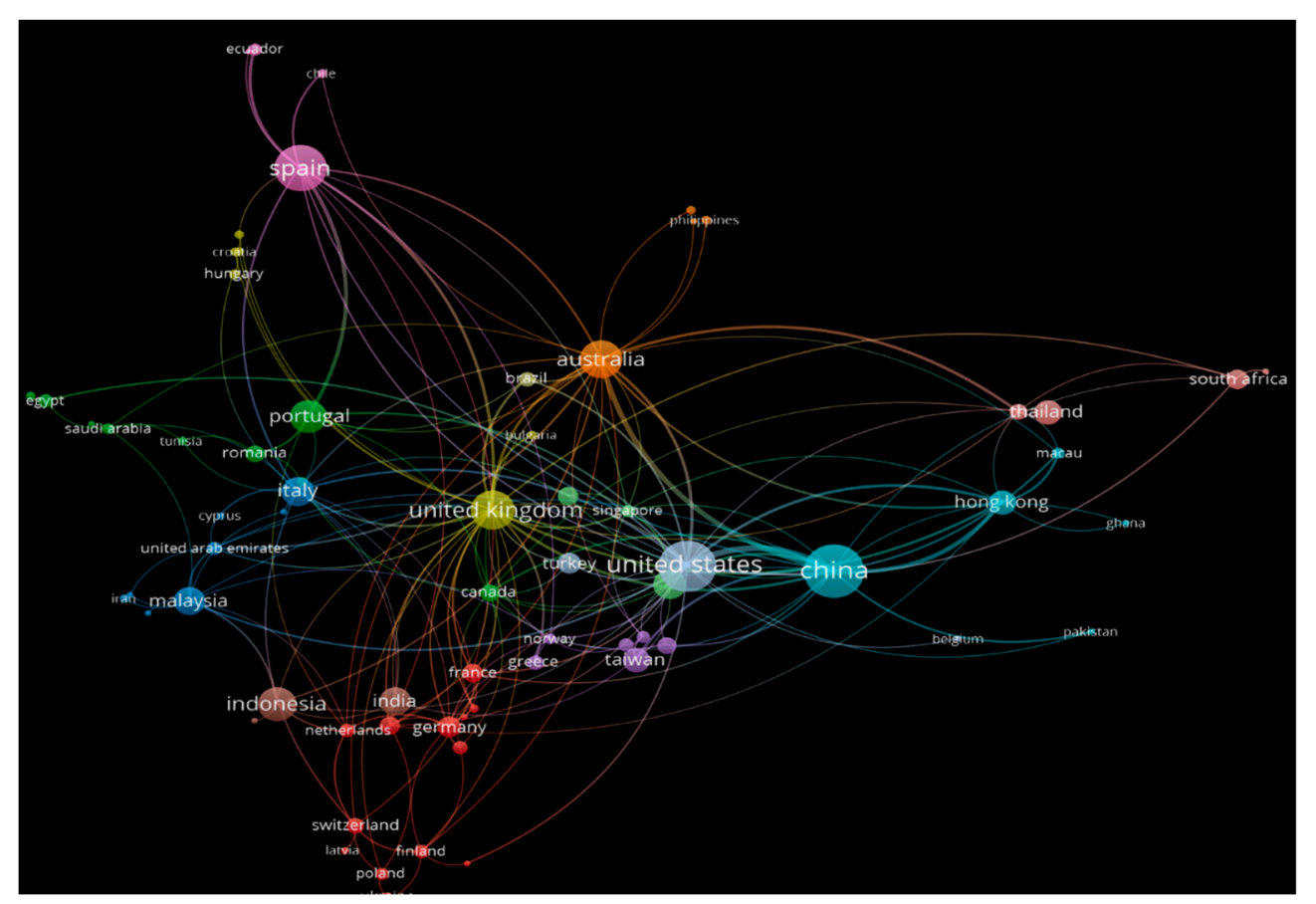

Figure 6. Collaborative research analysis.

\section{Conclusions}

This article reviews the technologies used in the tourism and hospitality industry from the year 2016 to 2020. This review's aim was the digital future of tourism development after the COVID-19 pandemic situation-the leading development in the tourism industry in recent times due to the digital technologies in literature. Research on the use of digital technologies in tourism is now established as an academic field, and the number and quality of publications are increasing rapidly. This trend is also noticeable in the global healthcare concerns after the COVID-19 pandemic, where the technology market is expected to expand. In the present study, the total numbers of full articles were 60 retrieved from the two databases, 'Web of Science' and Scopus, and thoroughly reviewed in PRISMA statement 2009. Besides, irrelevant and duplications are removed for better theoretical development for the current research. The final 60 articles are further classified into four major categories based on methodology, segment, settings, theories, and dimensions. The primary classification of literature is related to virtual reality and tourism, in that the literature mainly discusses the importance of virtual reality in the development of the tourism industry with the collaboration of virtual reality. Virtual reality significantly contributed to many other industries as a developing tool. Figure 7 is showing the literature outcome.

In the tourism industry, digital tourism literature contributes to the destination's development [42]. The virtual environments motivate consumers to visit the destinations. Besides, the second classification of literature is discussing virtual reality-related studies. The virtual environments technically change the entire setup of the industries and exceptionally entertaining world. The virtual environment purely dominates the gaming world, cinema, and multimedia-related industries. The consumers' perceived behavior is affected mainly by virtual reality in recent times [43]. However, the tourism industry also figures out in the literature to develop visitors' behaviors, mainly in cultural and heritage tourism, through digital tourism. Findings are primarily about the motivational factor 
toward using digital technologies in environments related to the development of tourism related. Additionally, virtual reality-related studies emphasize experimental research, and very few articles are related to exploratory research.

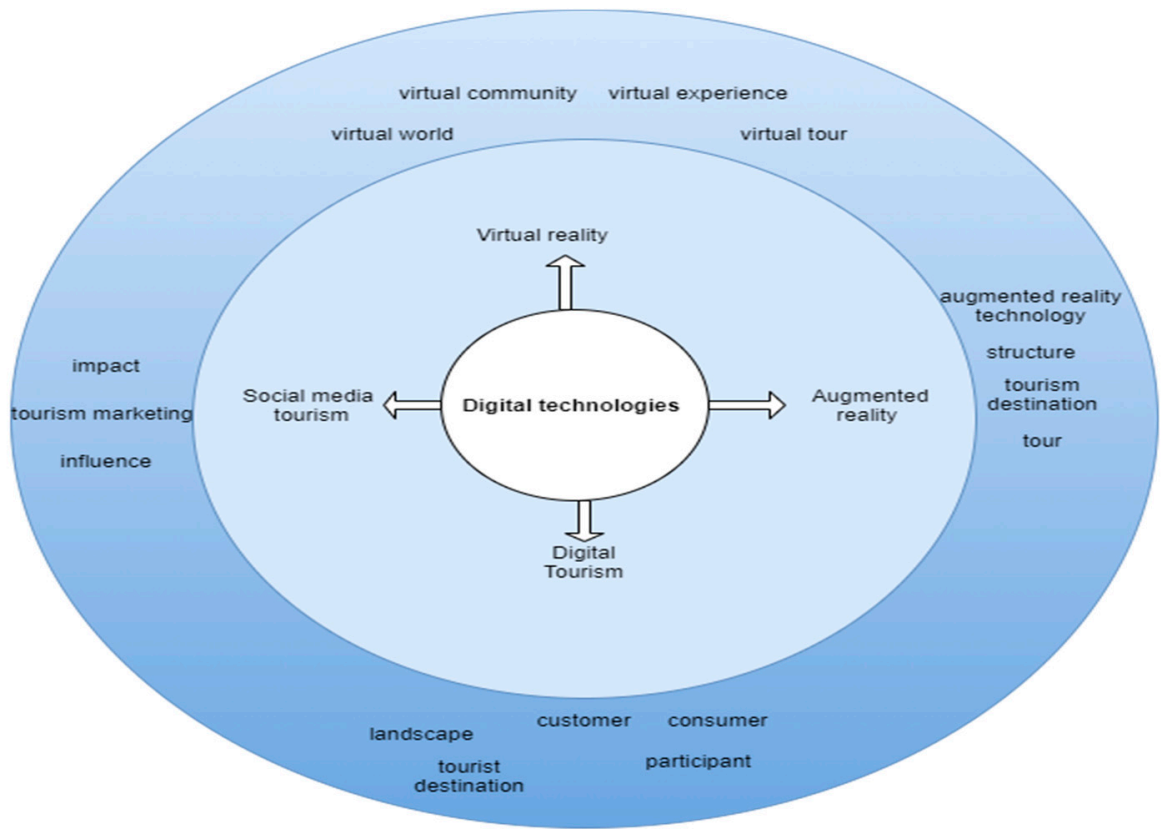

Figure 7. Classification of data and procedures.

However, the recent transformation of information from traditional mediums to digital mediums is much more influential and increases users' ability to make the information more straightforward and quicker. This review, the third significant findings in classification, is related to social media and augmented reality-based studies, discussing social media's role in tourism development using the virtual reality spaces. Social media is also a vital factor in the tourism and hospitality industry's growth. In the same manner, the adaptation of virtual reality is strengthening through using social media platforms. Social media is a significant contributor to cultural and heritage tourism promotion in recent years [44,45]. However, augmented reality literature also mainly discussed cultural and heritage tourism. Findings of literature related to augmented reality and virtual reality similarly emphasize the tourism and hospitality industry's promoting factor through technology. Overall results of the review demonstrate the digital technologies like social media, virtual reality, and augmented realities are vital for future digital tourism. Digital tourism can work across borders, and collaborative work among nations is already growing in recent years. The current study results show that significant collaborations are between Spain, China, and the United States. China has the highest number of collaborations with other countries.

\section{Future Agenda and Limitations}

Digital technologies are used for providing the information and destination outlook before visiting places, and the idea of convenience works. However, digital technologies can make it possible to normalize the tourism industry operational. Digital technologies are beneficial for older adults who cannot travel towards tourist destinations due to age. Technologies like virtual reality can entertain them in a much better way. The recent outbreak of COVID-19 now makes things a little different after the virus spread amongst visitors in many parts of the world. Host nations are more reluctant about travelers from different countries, and the situation is also similar to visitors. They would like to avoid traveling until the vaccination development procedures are completed. In this period, virtual reality and augmented reality options are more useful for visitors. However, many researchers believe that technology-based visiting does not experience actual visiting [36]. 
Still, restricted international travel and tourism activities are not open, and virtual reality is a better alternative to traditional tourism. It is a great challenge for researchers and scientists to satisfy the consumer's demand for tourism. The world scenario has changed entirely in recent years. Before COVID-19, tourism was an essential tool for communication between multicultural nations, but now nations are fighting to protect people. In this situation, virtual reality is a very vital tool for the tourism and hospitality industry. However, the future of tourism is still unprecedented due to the lockdown in many countries, and the adoption of substantial constraints on borderlines has also significantly affected the tourism economy worldwide. COVID-19 is heading to some encouraging consequences for the tourism industry. Declined demand in the aviation industry is already causing airlines to phase out outdated aircraft. Restrictions on overseas travel for international students, business travelers, and political leaders lead to increased leverage from videoconferencing.

Finally, like every study, this study is also not without limitations. This study contributes to the literature by elaborating on a detailed mapping of the existing literature on virtual reality and tourism studies that is a more significant challenge for sustainable development in the current circumstances. The methodology and classification process of research uses a better mapping and understanding of research after developing existing literature and dividing it into the three different classifications of tourism and virtual reality; however, this study still has limitations. Reference literature selected in this paper is already published in the Scopus and web of science-based journals that are entirely following the high reputation and quality in respective fields, making them very representative. Almost every article on eligibility criteria encompasses methodologies and empirical results, and review papers do not mention the empirical results and methodology. However, still, they are having a systematic picture of the review in the concerned field.

Author Contributions: This work was the output of collaborative research between researchers from different nationalities and institutions. N.K. and N.A. were responsible for the conceptualization of the idea, manuscript preparation and data analysis, and revision of the manuscript. The prepared manuscript was reviewed and amended by M.M.K. (Muhammad Mahroof Khan) and S.A. contributed to the revised manuscript and also secured article processing charges to facilitate publication of the research article., M.M.K. (Muhammad Muddassar Khan), S.S.H. and M.S.H. helped with reviewing and proofreading the final manuscript. All authors have read and agreed to the published version of the manuscript.

Funding: This research received no external funding.

Institutional Review Board Statement: No human or animals subjects were involved in the this research.

Informed Consent Statement: Not applicable.

Data Availability Statement: Data associated with this research will be available on request.

Acknowledgments: This work was a result of collaborative research between researchers from the UniKL Business School, Universiti Kuala Lumpur, Malaysia; the Faculty of Technology Management and Technopreneurship, Universiti Teknikal Malaysia Melaka, Malaysia; School of Urban Culture, Nanhai Campus, South China Normal University, Foshan 528225 China; University of Kotli Azad Jammu and Kashmir, Pakistan, Mirpur University of Sciences and Technology, Mirpur Azad Kashmir, Pakistan, and Abbottabad University of Science and Technology, Pakistan.

Conflicts of Interest: The authors declare no conflict of interest.

\section{References}

1. Beine, M.; Bertoli, S.; Chen, S.; Ambrosio, C.D.; Islam, N.; Koulovatianos, C.; Leduc, K.; Lorenz, N.; Peluso, E.; Peroni, C.; et al. Economic Effects of Covid-19 in Luxembourg First RECOVid Working Note with Preliminary Estimates; Research Luxembourg: Luxembourg, 2020.

2. Kayumovich, K.O. Prospects of Digital Tourism Development. Economics 2020, 23-24. [CrossRef]

3. Yeung, K.; Galindo, D. Why Do Public Blockchains Need Formal and Effective Internal Governance Mechanisms? SSRN Electron. J. 2019. [CrossRef] 
4. Gössling, S.; Scott, D.; Hall, C.M. Pandemics, tourism and global change: A rapid assessment of COVID-19. J. Sustain. Tour. 2020, 29, 1-20. [CrossRef]

5. Jones, P.; Comfort, D. The COVID-19 Crisis, Tourism and Sustainable Development. Athens J. Tour. 2020, 7, 75-86. [CrossRef]

6. Oztemel, E.; Gursev, S. Literature review of Industry 4.0 and related technologies. J. Intell. Manuf. 2020, 31, 127-182. [CrossRef]

7. Sarkar, S.K.; Toanoglou, M.; George, B. The Making of Data-Driven Sustainable Smart City Communities in Holiday Destinations. In Digital Transformation in Business and Society; Metzler, J.B., Ed.; Palgrave Macmillan: Cham, Switzerland, 2020 ; pp. $273-296$.

8. Ranasinghe, R.; Karunarathna, C.; Pradeepamali, J. After Corona (COVID-19) Impacts on Global Poverty and Recovery of Tourism Based Service Economies: An Appraisal. SSRN Electron. J. 2020. [CrossRef]

9. De Luca, G.; Dastgerdi, A.S.; Francini, C.; Liberatore, G. Sustainable Cultural Heritage Planning and Management of Overtourism in Art Cities: Lessons from Atlas World Heritage. Sustainability 2020, 12, 3929. [CrossRef]

10. Fauziah, C.L. The Geography of Accessibility: Assessing the Malaysian Approach to COVID-19 Pandemic Management. GEOGRAFI 2020, 8, 66-91.

11. Nurgalieva, G. The Islamic Economy-The Fastest Growing Large Economy. Eurasian Focus. SSRN Electron. J. 2018. [CrossRef]

12. Dencker, M. Software Is Feeding the World Develop Your Organisation to Sustain; Wiredelta: Copenhagen, Danmark, 2019.

13. Moher, D.; Liberati, A.; Tetzlaff, J.; Altman, D.G.; Antes, G.; Atkins, D.; Barbour, V.; Barrowman, N.; Berlin, J.A.; Clark, J.; et al. Preferred reporting items for systematic reviews and meta-analyses: The PRISMA statement. PLoS Med. 2009, 6. [CrossRef]

14. Rodríguez-López, N.; Diéguez-Castrillón, M.I.; Gueimonde-Canto, A. Sustainability, and tourism competitiveness in protected areas: State of art and future lines of research. Sustainability 2019, 11, 6296. [CrossRef]

15. Qureshi, M.; Khan, N.; Qayyum, S.; Malik, S.; Sanil, H.; Ramayah, T. Classifications of Sustainable Manufacturing Practices in ASEAN Region: A Systematic Review and Bibliometric Analysis of the Past Decade of Research. Sustainability 2020, $12,8950$. [CrossRef]

16. Lin, L.-P.; Huang, S.-C.; Ho, Y.-C. Could virtual reality effectively market slow travel in a heritage destination? Tour. Manag. 2020, 78, 104027. [CrossRef]

17. Lixing, Z. Impact of the COVID-19 Outbreak on the World and the Inspirations. Glob. J. Manag. Bus. Res. 2020, 29-37. [CrossRef]

18. Bogicevic, V.; Seo, S.; Kandampully, J.A.; Liu, S.Q.; Rudd, N.A. Virtual reality presence as a preamble of tourism experience: The role of mental imagery. Tour. Manag. 2019, 74, 55-64. [CrossRef]

19. Tussyadiah, I.P.; Wang, D.; Jung, T.H.; Tom Dieck, M.C. Virtual reality, presence, and attitude change: Empirical evidence from tourism. Tour. Manag. 2018, 66, 140-154. [CrossRef]

20. Rejón-Guardia, F.; García-Sastre, M.A.; Orfila-Sintes, F.; Garau-Vadell, J.B. Virtual reality in tourism: Centennials acceptance. Tour Anal. 2020, 25, 335-344. [CrossRef]

21. Errichiello, L.; Micera, R.; Atzeni, M.; Del Chiappa, G. Exploring the implications of wearable virtual reality technology for museum visitors' experience: A cluster analysis. Int. J. Tour. Res. 2019, 21, 590-605. [CrossRef]

22. Kim, M.J.; Hall, C.M. A hedonic motivation model in virtual reality tourism: Comparing visitors and non-visitors. Int. J. Inf. Manag. 2019, 46, 236-249. [CrossRef]

23. Han, D.-I.D.; Dieck, M.C.T. Calling for user-centric VR design research in hospitality and tourism. Hosp. Soc. 2019, 9, 237-246. [CrossRef]

24. Jude, O.C.; Ukekwe, C. Tourism and virtual reality (VR) in developing nations. Afr. J. Hosp. Tour. Leis. 2020, 9, 1-16.

25. Flavián, C.; Ibáñez-Sánchez, S.; Orús, C. Integrating virtual reality devices into the body: Effects of technological embodiment on customer engagement and behavioral intentions toward the destination. J. Travel Tour. Mark. 2019, 36, 847-863. [CrossRef]

26. Moorhouse, N. Virtual reality as an urban tourism destination marketing tool. Int. J. Technol. Mark. 2019, 13, 285. [CrossRef]

27. Wreford, O.; Williams, N.L.; Ferdinand, N. Together Alone: An Exploration of the Virtual Event Experience. Event Manag. 2019, 23, 721-732. [CrossRef]

28. Louw, C.; Louw, B.L. The digital disruption of virtual reality and the future of the steel roller coaster: An initial industry analysis. Afr. J. Hosp. Tour. Leis. 2018, 7, 1-16.

29. Orru, K.; Kask, S.; Nordlund, A. Satisfaction with virtual nature tour: The roles of the need for emotional arousal and proecological motivations. J. Ecotour. 2018, 18, 221-242. [CrossRef]

30. Marasco, A.; Balbi, B. Designing accessible experiences for heritage visitors through virtual reality. E-Rev. Tour. Res. 2019, 17, 426-443.

31. Shatnawi, T.; Ashour, L.; Kakeesh, D. Investigating the impact of atmospherics and online flow cues on visiting intentions: The case of Jordan' virtual tourist centre. Int. J. Electron. Mark. Retail. 2020, 11, 1-23. [CrossRef]

32. Schott, C.; Marshall, S. Virtual reality and situated experiential education: A conceptualization and exploratory trial. J. Comput. Assist. Learn. 2018, 34, 843-852. [CrossRef]

33. Buhalis, D.; Harwood, T.; Bogicevic, V.; Viglia, G.; Beldona, S.; Hofacker, C. Technological disruptions in services: Lessons from tourism and hospitality. J. Serv. Manag. 2019, 30, 484-506. [CrossRef]

34. Han, D.-I.; Jung, T.; Gibson, A. Dublin AR: Implementing Augmented Reality in Tourism. In Information and Communication Technologies in Tourism 2014; Metzler, J.B., Ed.; Springer: Cham, Switzerland, 2013; pp. 511-523.

35. Keckes, A.; Tomicic, I. Augmented Reality in Tourism-Research and Applications Overview. Interdiscip. Descr. Complex Syst. 2017, 15, 157-167. [CrossRef] 
36. Barrado-Timón, D.A.; Hidalgo-Giralt, C. The Historic City, Its Transmission and Perception via Augmented Reality and Virtual Reality and the Use of the Past as a Resource for the Present: A New Era for Urban Cultural Heritage and Tourism? Sustainability 2019, 11, 2835. [CrossRef]

37. He, Z.; Wu, L.; Li, X. When art meets tech: The role of augmented reality in enhancing museum experiences and purchase intentions. Tour. Manag. 2018, 68, 127-139. [CrossRef]

38. Gibson, A.; O'Rawe, M. Virtual Reality as a Travel Promotional Tool: Insights from a Consumer Travel Fair. In Augmented Reality and Virtual Reality; Metzler, J.B., Ed.; Springer: Cham, Switzerland, 2018; pp. 93-107.

39. Coghlan, A.; Carter, L. Serious games as interpretive tools in complex natural tourist attractions. J. Hosp. Tour. Manag. 2020, 42, 258-265. [CrossRef]

40. Muñoz-Leiva, F.; Hernández-Méndez, J.; Gómez-Carmona, D. Measuring advertising effectiveness in Travel 2.0 websites through eye-tracking technology. Physiol. Behav. 2019, 200, 83-95. [CrossRef] [PubMed]

41. Azarova, O.A.; Goryacheva, E.N.; Ilkevich, S.V.; Sevryukova, O.I.; Stakhova, L.V. Development of cross-cultural communication in international tourism. J. Environ. Manag. Tour. 2019, 10, 1376-1381. [CrossRef]

42. Flavián, C.; Ibáñez-Sánchez, S.; Orús, C. The impact of virtual, augmented and mixed reality technologies on the customer experience. J. Bus. Res. 2019, 100, 547-560. [CrossRef]

43. Peukert, C.; Pfeiffer, J.; Meißner, M.; Pfeiffer, T.; Weinhardt, C. Shopping in Virtual Reality Stores: The Influence of Immersion on System Adoption. J. Manag. Inf. Syst. 2019, 36, 755-788. [CrossRef]

44. Roma, P.; Aloini, D. How does brand-related user-generated content differ across social media? Evidence reloaded. J. Bus. Res. 2019, 96, 322-339. [CrossRef]

45. Khan, N.; Qureshi, M.I. A Systematic Literature Review on Online Medical Services in Malaysia. Int. J. Online Biomed. Eng. (iJOE) 2020, 16, 107-118. [CrossRef] 